\title{
The Amazon Basin in the Context of Shared Management of Transboundary Water Resources
}

\author{
Olga Kelman Brocki Calhman', Monica de Aquino Galeano Massera da Hora ${ }^{2}$ \\ ${ }^{1}$ Environmental Water Resources Laboratory, Department of Agricultural and Environmental Engineering, Fluminense Federal \\ University, Niteroi, Rio de Janeiro, Brazil \\ ${ }^{2}$ Master's Program in Civil Defense and Security, Fluminense Federal University, Niteroi, Rio de Janeiro, Brazil \\ Email: dahora@vm.uff.br
}

How to cite this paper: Calhman, O.K.B. and da Hora, M.A.G.M. (2017) The Amazon Basin in the Context of Shared Management of Transboundary Water Resources. Journal of Water Resource and Protection, 9, 629-636.

https://doi.org/10.4236/jwarp.2017.96042

Received: April 26, 2017

Accepted: May 19, 2017

Published: May 22, 2017

Copyright $\odot 2017$ by authors and Scientific Research Publishing Inc. This work is licensed under the Creative Commons Attribution International License (CC BY 4.0).

http://creativecommons.org/licenses/by/4.0/

\begin{abstract}
The present study addresses the issue of shared management of transboundary water resources, using the Amazon river basin as a case study. To evaluate risks, two scenarios (current and future) were simulated using the methodology proposed by the Transboundary Waters Assessment ProgrammeRiver Basins. The results obtained allowed the inference that the Amazon Basin, considering all indicators, is in the "moderate" category of risk within the current scenario. In turn, when only the "governance" indicator is considered, reflected through projected water politics tensions, the risk category for the basin becomes "high", both in the current and future scenarios (2030 and 2050). In conclusion, it is recommended that states should establish clear priorities and rules for water resource monitoring, use and supervision.
\end{abstract}

\section{Keywords}

Water Politics, Water Use Conflicts, Risk

\section{Introduction}

As mentioned by [1], natural resources are in the limelight, especially water resources, due to their uneven distribution across the planet. While water is abundant in some countries' territories, other countries experience shortage. In this regard, since many hydrographic basins occupy territories of more than one country, this can lead to a wide range of management scenarios, from conflicts to cooperation [2].

Environmental issues and the need for sustainable use of water resources 
again changed the approach to transboundary water resources at the end of the 20th century and in the early 2000s. [3] considered that "water became one of the main issues of the political agenda, both national and internationally".

According to [4], from this new perspective, the view of basins as management units has become strengthened, which makes upstream and downstream areas dependent on each other. In the Plate river basin, Brazil is located upstream [5]. In turn, regarding the Amazon basin, Brazil is located downstream. Additionally, the Amazon forest is the largest continuous rainforest and also the largest hydrographic basin in the world. Therefore, it is central in the transboundary water resources discussion.

According to the type of use that is desired, controlling springs or river mouths will be more strategic or more dependent in relation to a neighboring country. One example of this is water use for energy production, because countries located upstream are in a superior position. Conflicts can be observed, such as those experienced by Brazil and Argentina because of the construction of the Itaipu hydroelectric project, on the Paraná River, within the section shared with Paraguay. Argentinians, who receive waters from the Paraná River below its confluence with the Iguaçu River, at the triple frontier, were worried about the damming of the river, which would make Argentinian exploitation of its waters completely dependent on the outflow rate provided by the Brazilian-Paraguayan hydroelectric enterprise [4].

The objective of the present study was to provide a view of the status of water resource management in the Amazon basin. To achieve this goal, the methodology proposed by the Transboundary Waters Assessment Programme-River Basins (TWAP-RB), was applied.

\section{Physiographic Characterization of the Amazon Basin}

The Amazon river rises in Peru, in the Chila mountain range, at an altitude of 5170 meters and runs for approximately $7000 \mathrm{~km}$ until reaching the Atlantic Ocean, where it discharges an average of $220,000 \mathrm{~m}^{3} / \mathrm{s}$ (reaching up to 300,000 $\mathrm{m}^{3} / \mathrm{s}$ during the rainy season), accounting for $15 \%$ of the total freshwater volume worldwide that reaches the oceans [6].

According to [7], the Amazon River basin is the most extensive hydrographic network in the world. It occupies a total area of approximately $6,110,000 \mathrm{~km}^{2}$, from its springs in the Peruvian Andes down to its mouth in the Atlantic Ocean (northern Brazil), encompassing several South American countries: Brazil (63\%), Peru (17\%), Bolivia (11\%), Colombia (5.8\%), Ecuador (2.2\%), Venezuela $(0.7 \%)$ and Guiana $(0.2 \%)$, (Figure 1$)$.

CNRH resolution No. 32, of October 15, 2003, defines that in the Brazilian portion, the basin is called the Amazon Hydrographic Region, consisting of the Amazon river basin located within Brazilian territory, the basins forming the rivers of Marajó island and the basins of rivers in the state of Amapá that flow directly into the North Atlantic Ocean [8], encompassing an area of 3,869,953 $\mathrm{km}^{2}$. 


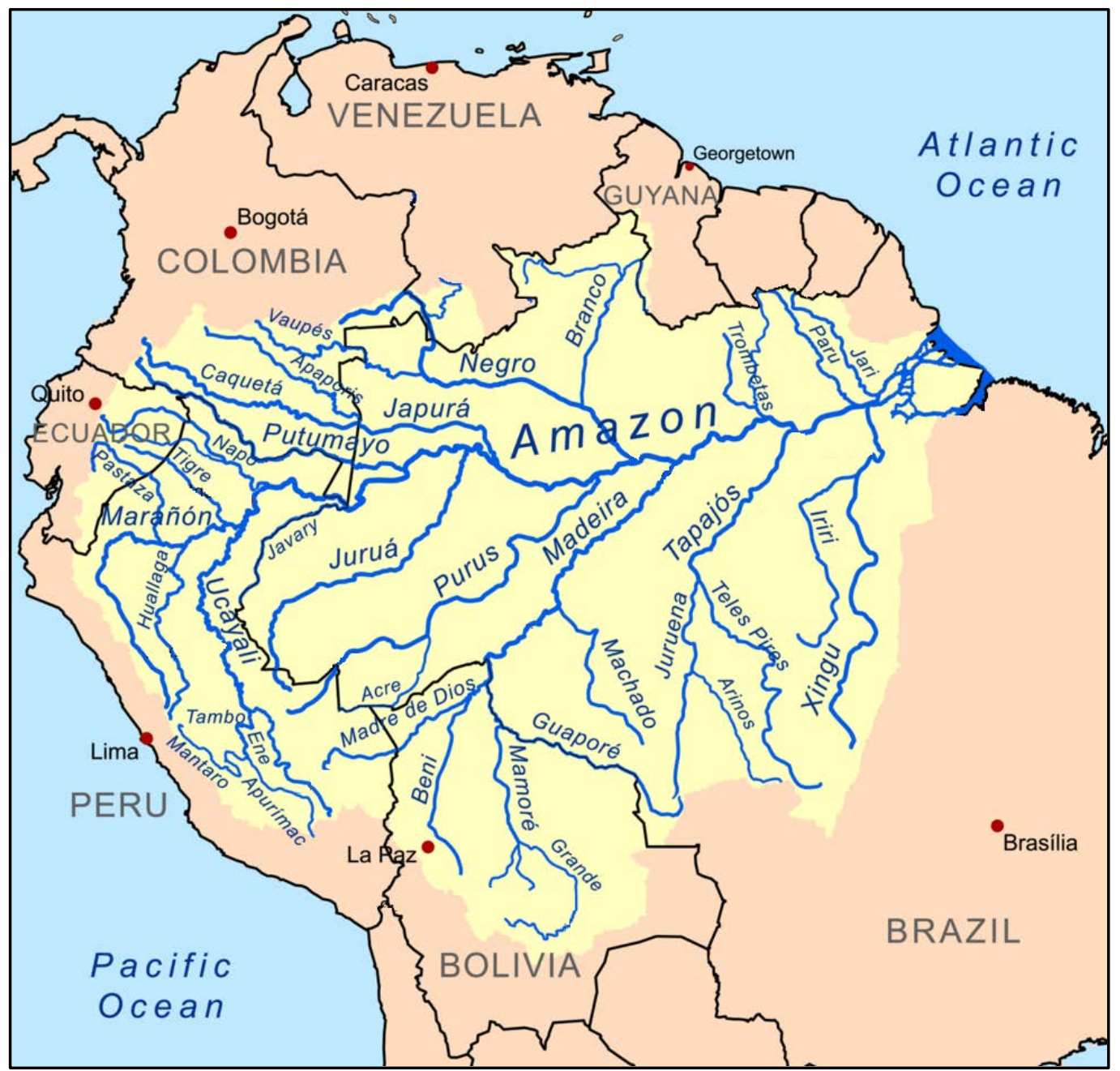

Figure 1. Map of the Amazon River basin (Adapted from [9]).

\section{Evaluation of the Legal Basis for Water Resource Management in Amazon Countries}

The relationships between states that involve transboundary water resources reveal a situation of interdependence, because the actions of one country may impact on another [10].

In the national context of Amazon countries, governments have mobilized considerable financial resources to exploit Amazon basin water resources for producing energy by building dams that are often destined to supply power demands elsewhere in the country. Construction of hydroelectric dams causes conflicts because people who were living in areas to be flooded are expelled, and in some cases, these areas are located within indigenous territories, causing impacts on these populations [11].

This issue is particularly important at the time when the National Water Agency (ANA), the Brazilian agency responsible for water resource management, grants concessions or authorizations to institutions or companies for them to exploit the hydroelectric potential. The mean monthly flow rates that correspond to the difference between the natural flow in the area of the enterprise and 
the consumptive uses upstream from this area are reserved for hydroelectric exploitation [12]. Thus, all water use upstream from the enterprise will be restricted to the values allowed by ANA. In the case of transboundary rivers (such as the Madeira river, which hydroelectric power exploitation at Jirau and Santo Antonio), the possible conflicts from this restriction could take on international proportions [13]. This concern was also expressed by [14], who mentioned that expansion of the generation capacity of the hydroelectric sector will demand deeper knowledge of the area where this will take place, with permanent follow-up of power generation conditions.

The bases for shared management of transboundary basins are policies, cooperation and institutions [1]. In this regard, knowledge of the specificities of the legal framework and institutional arrangements of water resource management of the countries involved, with identification of the existing congruencies and divergences, is necessary in order to achieve progress in shared management of transboundary water [15]. One of the main advances in the legal system regarding water resource management in Amazon countries has been recognition of the basin as a water resource management unit [4].

According to [9], each of the countries that form part of the Amazon Basin has a particular management model structured as a function of its own legislation and the set of instruments that exist, and the framework of principles embodied in each legal system. Regarding water resource management policies, this author states that: “... countries such as Brazil, Venezuela and Peru have specific legislation and normative instruments with advanced characteristics, since these establish an institutional structure for decentralized participative management that is based on multiple water use. In turn, Colombia is in an intermediate stage, since it does not have specific laws for structural and instrumental organization regarding water management. Nonetheless, the general environmental law provides various prescriptions about the issue."

Also according to this author, Bolivia and Guiana does not have water resource policies that delineate water management premises because they only have generic environmental legislation, in which there are no instruments regarding water resources.

On the other hand, in Ecuador, an organizational law on water resources, use and exploitation was approved in the National Assembly on August 6, 2014. Its legal framework is similar to that of the laws in Brazil, Venezuela and Peru. It aims towards decentralized and participative management with the objective of assuring protection, conservation, integrated management and sustainable exploitation of surface and groundwater reserves.

As a consequence of the legislative scenario, [9] listed the following possible conflicts:

- Losses regarding water quality and quantity due to the absence of a water resource plan;

- Difficulties of interlocution between agencies responsible for water resource management; 
- Possibility of inconsistency of integrated decisions due to insecurity or lack of information;

- Curtailment of management control by states and society;

- Risk of pollution of Amazon River basin waters due to absence of charges for untreated water.

\section{Evaluation of Risks Relating to Water Resource Management in Amazon Countries}

The methodology used in the present study was as proposed by the Transboundary Waters Assessment Programme (TWAP), which was started by the Global Environment Facility (GEF) in order to create the first transboundary water resource assessment of the planet [16].

The programme enables verification of the status of each transboundary basin through using indicators to simulate scenarios at the baseline (current) and in 2030 and 2050 (future), encompassing five groups of systems: 1) groundwater; 2) lake basins; 3 ) river basins; 4) large marine ecosystems; and 5) open ocean. For the present study, the Transboundary Waters Assessment Programme-River Basins (TWAP-RB) was used, which is available at

http://twap-rivers.org/indicators/.

The TWAP-RB uses methodology that encompasses a certain number of indicators, with comparative analysis between basins. Five thematic groups were identified as being relevant to populations and ecosystems: water quantity, water quality, ecosystems, governance and socioeconomics. The assessment establishes relative levels of risk ranging from 1 to 5 , as shown in Table 1 .

\section{Results and Discussion}

From the simulation in the TWAP-RB website for the Amazon River basin and its respective sub-basin units (BCU-basin country unit), the risk scenario assessments (baseline) shown in Table 2 were obtained.

Regarding the projected scenario (2030 and 2050), considering that the TWAP-RB does not necessarily simulate the same indicators as the "baseline" scenario, we decided to present results relating to the thematic groups "water quantity" and "governance", in Table 3.

Table 2 allows the inference that, in the baseline scenario, the Amazon basin is within the risk categories "very high", in terms of water quality (water pollution), and "high", in terms of governance (water politics tension and legal framework). These results were also shown by [15]. In the baseline scenario,

Table 1. Risk categories (Adapted from [16]).

\begin{tabular}{ccc}
\hline 1 & Very low \\
2 & Low \\
3 & Moderate \\
4 & High \\
5 & Very high \\
\hline
\end{tabular}


Table 2. Indicators per territory and total indicators in the Amazon basin: baseline scenario.

\begin{tabular}{ccccccccc}
\hline \multirow{2}{*}{ BCU } & \multicolumn{2}{c}{ Water Quantity } & $\begin{array}{c}\text { Water } \\
\text { Quality }\end{array}$ & Ecosystems & Governance & Socioeconomics \\
\cline { 2 - 9 } & A1 & A2 & A3 & B & C & D & E & F \\
\hline Brazil & 1 & 1 & 4 & 5 & 1 & 4 & 3 & 1 \\
Bolivia & 1 & 2 & 3 & 5 & 1 & 4 & 3 & 4 \\
Colombia & 1 & 2 & 3 & 5 & 1 & 4 & 3 & 1 \\
Ecuador & 1 & 2 & 3 & 5 & 1 & 4 & 3 & 3 \\
Guiana & 1 & 1 & 3 & 5 & 1 & 2 & 3 & 1 \\
Peru & 1 & 2 & 2 & 4 & 1 & 4 & 3 & 3 \\
Venezuela & 1 & 1 & 4 & 5 & 2 & 2 & 3 & 1 \\
In the basin & 1 & 2 & 3 & 5 & 1 & 4 & 3 & 3 \\
\hline
\end{tabular}

Legend: (A1) Human water stress; (A2) Environmental water stress; (A3) Exposure to floods and droughts; (B) Pollution due to waste water; (C) Impacts caused by dams; (D) Water politics tension; (E) Legal framework; (F) Economic dependence on water resources.

Table 3. Indicators per territory and total indicators in the Amazon basin: 2030 and 2050 scenarios.

\begin{tabular}{|c|c|c|c|c|c|}
\hline \multirow[b]{2}{*}{$\mathrm{BCU}$} & \multicolumn{4}{|c|}{ Water Quantity } & \multirow{2}{*}{$\begin{array}{c}\text { Governance } \\
\text { Projected Water Politics } \\
\text { Tension }\end{array}$} \\
\hline & $\begin{array}{c}\text { A1 } \\
(2030)\end{array}$ & $\begin{array}{c}\mathrm{A} 1 \\
(2050)\end{array}$ & $\begin{array}{c}\text { A2 } \\
(2030)\end{array}$ & $\begin{array}{c}\text { A2 } \\
(2050)\end{array}$ & \\
\hline Brazil & 1 & 1 & 2 & 2 & 4 \\
\hline Bolivia & 1 & 1 & 2 & 2 & 4 \\
\hline Colombia & 1 & 1 & 2 & 2 & 4 \\
\hline Ecuador & 1 & 1 & 2 & 3 & 4 \\
\hline Guiana & 1 & 1 & 2 & 2 & 2 \\
\hline Peru & 1 & 1 & 3 & 3 & 4 \\
\hline Venezuela & 1 & 1 & 2 & 3 & 2 \\
\hline In the basin & 1 & 1 & 2 & 3 & 4 \\
\hline
\end{tabular}

Legend: (A1) Human water stress; (A2) Environmental water stress.

regarding human and environmental water stress, the basin presented "very low" and "low" risks, respectively. There was also moderate economic dependence on water resources in the basin, which was mainly due to the high-risk values for Peru, Bolivia and Ecuador.

In the future scenario (Table 3), projected for 2030 and 2050, as identified by [9], the Amazon basin presented its highest risk in the "governance" indicator (projected water politics tension). The countries that contributed the most towards increasing this result were Bolivia, Brazil, Colombia, Ecuador and Peru. Regarding water quantity, from 2030 to 2050, the risk that corresponded to "environmental water stress" increased, changing from "very low" to "moderate".

\section{Conclusions}

The Amazon countries' shared management of water resources is still at a very 
early stage because of differences in the legal basis, interlocution difficulties and lack of information, which hinder cooperation. Although the countries involved accept that the basin is a single territorial management unit, and has the political and strategic characteristics of transboundary water resources, the institutions responsible for its management in one country do not always have an equivalent in a neighboring country, especially regarding laws. This situation represents an impasse in constructing a shared management process.

It is convenient for states to establish their priorities and, jointly and consensually, to establish clear agreements and rules for water monitoring, use and supervision. This procedure should be performed in an integrated manner, with observance of international agreements, which should produce compatibility between the management policies and instruments of the countries involved.

\section{References}

[1] Dias, D.D.G. (2014) Os recursos hídricos como gestão compartilhada nas fronteiras da América do Sul e a Bacia Amazônica em questão. $1^{\circ}$ Congresso Brasileiro de Geografia Política, Geopolítica e Gestão do Território: Racionalidades e práticas em múltiplas escalas ( $1^{\circ}$ CONGEO), Rio de Janeiro: Editora Letra 1, 853-862.

[2] Calhman, O.B.C. (2008) Gestão de Recursos Hídricos em Bacias de Rios Fronteiriços e Transfronteiriços: Rio Quaraí/Bacia do Prata. 302f. Tese (Doutorado), Instituto Alberto Luiz Coimbra de Pós-Graduação e Pesquisa de Engenharia, Universidade Federal do Rio de Janeiro, Rio de Janeiro, RJ, Brasil.

[3] Soares, G.F.S. (2002) Curso de Direito Internacional Público. Atlas, São Paulo, 442 p.

[4] Brasil (2013) Secretaria de Assuntos Estratégicos da Presidência da República. Água e Desenvolvimento Sustentável-Recursos Hídricos Fronteiriços e Transfronteiriços do Brasil. Série Estudos Estratégicos, Brasília, 144 p.

[5] Calhman, O. and Hora, M. (2016) Shared Management of Water Resources among Sovereign States in Latin America: The Case of the River Plate Basin. Journal of Environmental Protection, 7, 1089-1095. https://doi.org/10.4236/jep.2016.78097

[6] Migyiama, A.C. (2011) Desafios e oportunidades para a gestão integrada dos recursos hídricos da bacia do rio Amazonas. 122f. Dissertação (Mestrado), Universidade Federal do Pará, Núcleo de Meio Ambiente, Mestrado em Gestão de Recursos Naturais e Desenvolvimento Local na Amazônia, Belém, PA, Brasil.

[7] ANA (2016) Agência Nacional de Águas. Região Hidrográfica Amazônica: A maior do mundo em disponibilidade de água.

http://www2.ana.gov.br/Paginas/portais/bacias/amazonica.aspx

[8] BRASIL (2003) Resolução no 32, de 15 de outubro de 2003. Institui a Divisão Hidrográfica Nacional. Diário Oficial da República Federativa do Brasil, Brasília, 17 dez. http://www.cnrh.gov.br/index.php?option=com content\&view=article\&id=14

[9] Musser, K. (2008) Amazon River Basin. https://commons.wikimedia.org/wiki/File:Amazonriverbasin basemap.png

[10] Ribeiro, W.C. (2008) Geografia Política da Água. Annablume, São Paulo.

[11] Sant'anna, F.M. (2012) As fronteiras políticas na Bacia Amazônica e a cooperação para a utilização dos recursos hídricos compartilhados. XII Colóquio Internacional de Geocritica, 2012, Bogotá, Colômbia. Independencias y construcciones de estados nacionales: poder, territorialización y socializaciónsiglos XIX-XX. 
http://www.ub.edu/geocrit/coloquio2012/actas/05-F-Mello.pdf

[12] ANA (2009) Agência Nacional de Águas. Manual de Estudos de Disponibilidade Hídrica para Aproveitamentos Hidrelétricos-Manual do Usuário. Agência Nacional de Águas (ANA), Brasília, 45 p.

[13] Hora M.A.G.M. and Legey, L.F.L. (2015) Water Resource Conflict in the Amazon Region: Hydropower Generation and Multiple-Use Water Systems in the Tocantins and Araguaia River Basins. Journal of Water Resource and Hydraulic Engineering, 4, 229-235. https://doi.org/10.5963/JWRHE0403002

[14] Freitas, M.A.V. and Soito, J.L.S. (2008) Energia e recursos hídricos. Parcerias Estratégicas, Brasília, n. 27, 177-215.

[15] Ribeiro, C.R., Bermudez, O.B. and Leal, A.C. (2015) A Gestão Compartilhada de Águas Transfronteiriças, Brasil e Colômbia. Mercator, Fortaleza, 14, 99-118. https://doi.org/10.4215/RM2015.1402.0007

[16] UNEP (2016) Transboundary River Basins: Status and Trends. United Nations Environment Programme (UNEP), Nairobi.

\section{Scientific Research Publishing}

\section{Submit or recommend next manuscript to SCIRP and we will provide best} service for you:

Accepting pre-submission inquiries through Email, Facebook, LinkedIn, Twitter, etc. A wide selection of journals (inclusive of 9 subjects, more than 200 journals) Providing 24-hour high-quality service User-friendly online submission system Fair and swift peer-review system Efficient typesetting and proofreading procedure Display of the result of downloads and visits, as well as the number of cited articles Maximum dissemination of your research work

Submit your manuscript at: http://papersubmission.scirp.org/ Or contact jwarp@scirp.org 